\title{
Centromere Protein X
}

National Cancer Institute

\section{Source}

National Cancer Institute. Centromere Protein X. NCI Thesaurus. Code C116633.

Centromere protein $X(81 \mathrm{aa}, \sim 9 \mathrm{kDa})$ is encoded by the human CENPX gene. This protein is involved in the processing of DNA replication forks, DNA binding and DNA repair. 